\title{
"A Turma da Mônica" comic book "A story that needs an end" and the education about drugs: a vicious circle and transition.
}

\author{
Maria de Lourdes da Silva \\ Adjunct Teacher \\ Universidade do Estado do Rio de Janeiro-UERJ \\ Francisco José Figueiredo Coelho \\ Researcher \\ Grupo Interdisciplinar de Educação, Eletroquímica, Saúde \\ Ambiente e Arte-GIEESAA/UFRJ \\ Maria Fernanda Batista Bittencourt Guimarães \\ Student \\ Faculdade de Educação \\ Universidade do Estado do Rio de Janeiro-UERJ
}

\begin{abstract}
Summary
This article analyses the discourse present at: "Turma da Mônica" comic book entitled "A story that needs and end", published in 2002. A quantitive analyses considered both the images and the speeches taking as theorical and methodological reference by Mikhail Bakhtin. Through the Author we notice that the social interaction gives a new meaning to heading and makes sense considering the production context. Following this path, the text tries to answer a group of questions about the way the comic book acts into the direction to the maintenance of the ideological policy guidance to the war to drugs, besides its original context and the first orientation given by the Brazilian educational law. Taking into consideration all these questions an analyses of the material indicates that besides the initial proposes, the ambiguity and contradiction of the discourse sustained by the headings linked to the prohibiting policy, forbids the questioning and increases the space to the update reproduction of the punishing-reprimanding demands.
\end{abstract}

Keywords: Education on drugs, didactic material on drugs, educational policy for drugs; "Turma da Mônica".

\section{Introduction:}

In Brazil, talking about drugs at school is not na easy step. Its understandable the resistance and embarrassment of teachers to talk about themes when the context deals with the recreative and abusive use of drugs besides, drug dealers are present at their daily lives. This refusal of the education branch has been discussed by the teaching/educating literature field with an emphasis since the decade 1990 (COELHO, 2019), at that moment the government published National Curriculum Parameters $-\mathrm{NCP}^{1}$ about health. According to this guideline, the educational parameters dedicated to the third and fourth phases of Elementary School, an important part of this material is worried about the approach to drugs at school, bringing to reflection an education more collaborative and concerned with the prevention context to students (BRASIL, 1998; COELHO, 2019).

In this paper, we can see the experience of youngers with drugs as part of a developing process of identity and sociability. The NCP have a propose to the drug theme openly to the different possibilities of experiences, so that teachers and students may deal with the complexity that the topic requires, promoting debates, clarifying and informing about recent published scientific articles that state the same as Francisco Coelho (2019) proposes though the offer of moments of learning and discussing about drugs at school. Regarding the different suggestions and deconstruction proposed by the NCP, three have a main role here. The first one: the evidence of a real context for the use of drugs: the pleasure. Through this, the parameters recognize to kids and youngers, that the drugs cause pleasure and are among human society since long. According to the document:

\footnotetext{
${ }^{1}$ The National Curriculum Parameters-PCN, published in 1997, developed a Brazilian educational law applied to ensure that cross-cutting themes, taken as fundamental issues for the formation of the Brazilian citizen, are used in school. Cross-cutting themes include work, ethics, environment, sexual orientation, consumption, cultural plurality and health. In this article, we focus on the last crosscutting theme.
}

60 
The use of different substances psychoactive ones at work, for entertainment or rituals and parties, playing the role of joining communities, is common to all cultures, and the social and religious use of drugs, pleasuring ones, capable of modifying the mood, perceptions and sense has been a constant through human history. (NCP- - Health, 1998, p. 271).

The second remark done by the NCP is the sensibility to the importance of the role of the teacher and the educational institution in promoting debates and building new understanding and posture on the theme cultivated at the school space. In this perceptions it is emphasized:

Preventing the risks, the expropriate use of drugs is at a separate chapter. The size of the social demand to the treatment of the theme make it necessary emphasize the difficult in dealing with the subject, the hope is in the teacher's hand and a lot is expected from the education institutions. Undoubtedly, the school is a privileged space for the debateon the topic once the understanding of the reasons for the use of drugs is directly related to the emotional relationships and social interaction of kids and youngers, including at school. (NCP - health, 1998, p. 271).

The third remark done by the NCP says that it must be aroused the leading of students recognizing their emotional and social reality, giving them means so that their questions and opinion may be considered at school. It recognizes that: It is not possible to treat the question at school as if it were an island. Recognizing facts and myths about the topic, the real situation of use and abuse of drugs in different realities, as the ideas and feelings of the students, the schoolar community and parents must it all be considered. (NCP - health, 1998, p. 271).

As far as legislation that not only proposes the treatment of the theme by the schools as it opens the possibility to bring to the school space the knowledge produced by science to anchor and guide the discussions about the theme, our research has been dedicated to analyze the production of educating material (books, games, comics etc.) that emphasize the role of preventive education on drugs. On our present paper we analyze the comic "Turma da Mônica", "A Story that needs an end" (2002), published by Maurício de Sousa Productions and the Brazilian Government. The comic was bought by SENAD - National Secretary of Drugs policy called at that time National Secretary Antidrug ${ }^{2}$, to be distributed freely at public elementary schools of the country. Throughout 17 years since it was first published, the comic book is included in primary prevention campaigns to drugs especially at schools.

Following the recommendations of SENAD and the educational remarks about the topic (mainly those on the NCP described before), the publishing team made an effort to incorporate to the comic book the legal orientations of the secretary, at the time more enthusiastic to promote the school as a space of discussion on the matter, mainly having the teachers as the principal channel to promote this debate, being them, capable to expose it to families and the community - and that isn't it all, considering that the illegal condition of the drugs may criminalize the debate.

The copies of these comic books were distributed freely at schools throughout these years and, in the beginning of 2019, a fake news spread by the internet app WhatsApp directed to parents informed:

Dear parents - Mr. Bolsonaro requested and the Federal Government, through the anti-drugs crew, elaborated a comic book to teach the kids to protect themselves against drugs and besides help identify their friends that maybe involved with them in order to offer help. With the partnership of Mauríciode Sousa, who had an enormous satisfaction in helping the President Bolsonaro it was published this comic book with the "Turma da Mônica". I recommend that you print and read it with your kids before going to bed and talk to them. (Unknown).

It is important to remember that not only this mistake and misunderstanding information about drugs has been spread both by WhatsApp as other social networks, part of these has been spread by the health prevention campaigns, mainly those centered in the prohibition approach. These mistakes and points of view may cause different scarf and prejudgment as pointed out by several authors (HART, 2014; ACSELRAD, 2015; COELHO, 2019). A recent research by Coelho emphasizes besides being incorporated by the NCP about health (1998), the education on drugs is reinforced by the present drugs law nr. 11.343/2006 that establishes that teaching institution should promote preventive actions. On the other hand, studies show that the pedagogical team, mainly teachers are unprepared to deal with the topic even nowadays (COELHO, 2019).

Further, it is important to give emphasis that the NCP is worried about the reduction of the debates about drugs at school. In discordance with the practice evidences to youngers and their daily lives, the official speeches to combat drugs suggest that they are illegal and mysterious and the users called the others are thieves and drug dealers who must be excluded from the social lives (BRASIL, 1998).

\footnotetext{
${ }^{2}$ SENAd was created in 1998 and was linked to the Presidential Institutional Security Office. It was born as the National Anti-Drug Secretary. Its name was changed in 2011, when it ceased to be directly linked to the Presidency of the Republic and became subordinate to the Ministry of Justice.
} 
As states Coelho (2019), this may make it difficult the understanding of the topic by youngers and corroborate with the scarf and mythification on the theme, perspective present at Hart's work (2014) and Acselrad's (2015). Mainly by the pedagogical point of view, there is an agreement in literature mentioned that make use of drugs, even if at a regular way, doesn't meen that the person is an addict.

Part of our workhas as its goal investigate didactics material and paradidactics on drugs as also the graduation of teachers of the public-school system. For the reason, although there are other publishings by Maurício de Sousa Productions based on the drugs theme, the comics "Turma da Mônica" called the attention by the fact of the fake news state that it could figure as a good sample of the thoughts of the new government concerning drugs, mainly at the educational and family field. Although we have understood the limits and problems of the comic book and about it there has been much talk on courses and classes, the message highlighted in us the urgent necessity to deeply study it in order to understand the ways it evokes the reinforcing meaning punishing-repression that gets strength through it.

For all these and following the investment on research of didactic material and paradidactic on drugs by Maria de Lourdes da Silva, teacher, we decided to recut the comic in screen for a deeper and caution analyses in order to answer the following doubts: 1 - Which elements present at the comic book give it the credential to be a representative of the interests of the new government under review? 2 - In what ways the present policy reinforces some senses of the comic book, even being it proposed to value teacher, a professional that has been much attacked by the present governmental policy? 3 - How education and teachers can resist to these senses about drugs at the school area and in education in general? 4 - How the new drugs policy ${ }^{3}$ approved in April 2019, gets the comic book on the centripetal force from the interests of the new policy of the Brazilian government?

In short, the aim of this work is to analyze the dialogues present at the comic book of "Turma da Mônica" entitled "A story that needs an end" in a discourse approach view. In this deep examine were taken into consideration both texts and images as both contribute to the construction of the senses and representations on the matter here discussed.

\section{Methodology}

The research has a quality approach based on the methodological discourse analyses by Mikael Bakthtin (1986). We took into consideration that the text analyses (and images) could only reach the meaning of a text if we take part of the structure both imagens and the discursive of texts. These pictures represent though sensitivities aesthetic, once the discourse efficiency of the imagens is more immediate than the verbal or written one.

Both are ideological and political conformed in the inepterutive chain of verbal social interaction once the signs and symbols are ideological. The imagens are "read" interpreted though the headings and make text that materialize the ideas and organize visions of the world and ways to take part of it.

The headings the small units of discourse intersection are the means of a concrete discourse manifestation. They are the live form of communication, linked to the social environment in its contingencies and are modulated by the context. These are not simply juxtaposed as if they were indifferent one to another, they meet in an interaction situation, in tense conflicts and interruptible ones (BAKHTIN, 1986, P.107). The act of thinking is not accidental. Each of us think what can be thought in the place where we are, conduced and conditionated by the terms that surround and determine us. This because the consciousness conforms itself in the social interaction, because each person has an specific story and organizes it on modules of meaning of the lived experiences.

The author says that "everything is an act or action that you realize - even the thought and the feeling" (p.23). When the mind activity is done by the form of an enunciation, the social orientation in which it is submitted acquires more complexity thanks to an adapting demand to the social context immediate of the act of speaking and alive in all the concrete interlocutors (BAKHTIN, 1986, p. 87). For this the materiality of the acts of speech is related to the verbal interaction which is conditioned to ideological political context and to the processes of the social regulation, being a life expression of the potency that escapes and innovates the regulatory processes which aim to stabilize the abstract modules senses when presented in the form of a book, when the acts of speech instituted themselves in written discourse, even though they insert themselves into the uninterruptible verbal chain as member of an ideological discussion in big scale (BAKHTIN, 1986, p. 123) refuting, confirming or answering something, anticipating answers, objections, supports etc. One reading, thus takes other voices besides the one of the announcer. For this feature we say the discourses are dialogues.

\footnotetext{
${ }^{3}$ The New National Drug Policy was instituted by Decree No. 9,761 in April 11, 2019. In general terms, the decree excludes harm reduction policies in health care; regains hospitalization to users, compulsorily, if necessary; it makes prohibitionist teaching of drugs compulsory in school units, among others.
} 
Based on dialogism we consider analyze the way the headings of the comic book (present at its texts and images) reinforce the fake news mentioned before working as a centripetal force of the reactionary projects of the new government. Taking into account the references above described, we will consider the group text-image as necessary elaborate representations. The starting point we took was to understand how the headings in the comics express educational aims proposed in the first production context. After analyzing the update mechanisms of the senses produced by nowadays picture. As the enunciative dynamics are always changing, it is important to notice how the senses changes the proposed views, having always a margin reference as starting point.

Before going ahead in that direction, its advisable to add what Manuel Jacinto Sarmento says about what he calls infant culture:

Though this concept it is understood the capacity that the children have of building in a systematic patter to their world meaning of intentional action, which are distinct from an adult action and meaning (2002, p. 05).

The author explains that specific tools are necessary to get into the childish world, as symbolic references already known by the kids, for instance. Considering the comics analyzed, it deals with a group of well-known characters in children literature "The Turma da Mônica", through which it is intended to share an educational concept on drugs. This would make it easier to accept the message brought by the characters who are well-known and popular among kids. Besides that, other elements present at the current childish literature as bogeyman, the split world between good and bad and the high price by the disobedience, for example, they are basic conductors of the speech in screen. Though, points Sarmento, this power of determing the raising of senses and meaning in kids is not automatic.

One of the most persistent conclusions stated by the analyses of the goods industry, mainly cultural ones, concerning TV shows for kids, is the fact that much on the contrary to what is currently stated by common sense, kids are not receptors, passive, uncritical and reproductive of these shows, much on the contrary, even if they establish connections to them, this is a critical and creative link and even too critical of those messages. (BUCKINHAN, 1994, 200, apud SARMENTO, 2001, p.7).

It is important to take into consideration the acquiring processes of the stories by the kids as accurate and selective ones drunken to the conditions of the immediate reading as to the social history context into which are immerse and their idiosyncrasies.

To suppose as passive activity of the kids to the production of senses caused by the world and their histories, betting on the resources used in these productions to infancy, by the symbolic figure they bring, as inescapable tracks to the elaboration of sense, this means to impoverish their capacity to elaborate new meanings to the world and life. That is, there is no passivity and simple reproduction in the experiences lived by kids even if this passivity is praised and the active thought condemned. In the limits of this paper, we are not working with the world reading processes by the kids as once we care about the intentions of the comics production. Though, as the characters of the comics are kids, we are using the behavior of these characters, as the value contest linked to their speeches, in order to understand the behavior parameters accepted and not accepted given by the story.

\section{3 - Result and Discussion about the analyses of the comic book}

\section{1 - The "Turma da Mônica" and the comics}

The "Turma da Mônica" is, maybe, the most famous kids comic book in Brazil. Its author, Maurício de Sousa, created the "Turma or Turminha da Mônica" in honor of his daughter as a child, in 1959 and kept developing the characters throughout the years. In the 1970's, when new languages were requested by the pedagogies as a means of multiplying and diversing the teaching-learning processes, the comics began to be part of the educational space (VERGAA) the popularity reached by the comic make it a governamental means to different public campaigns, being the drugs only one of them.

"A story that needs an end" is not a simple title. It brings a kind of anguish and hurry in relation to the drugs question. Making an immediate empathy and convergency among those that wish an end to the question - this is a heading that updates others, lined to the field of the "war against the drugs" from which is taken the repertory of the end of the drugs, from the extermination. The emotional link is established before the reasoning on the means to actualize the proposal. The identification of the readers with the explicit proposition in the title diminishes a critical act to the reading.

The cover of the comic book presented in picture 1 in an intense pink tone, opposes graphic and spatially, Monica's group to the character Zélio, the drug user in the plot. With a ghost shadow of a Zélio, a drug dealer carrying drugs that the skull points as illegal smuggled by a pirate symbol. (ZWETSCH, 2013, p. 24). 


\section{Picture 1 - Cover of the comic book "Turma da Mônica"}

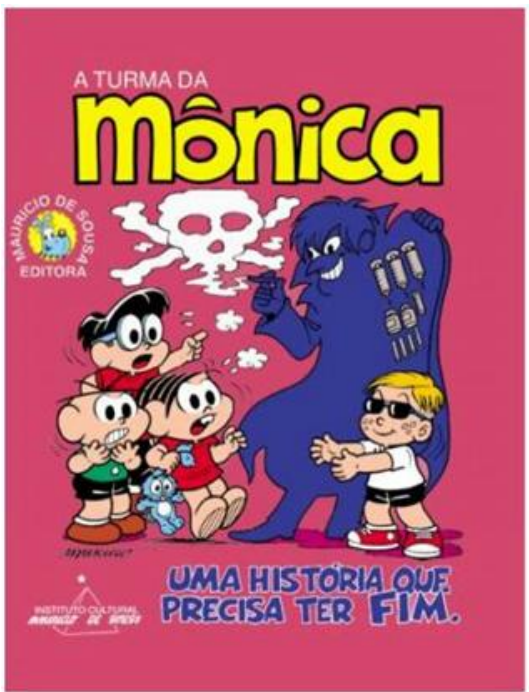

Resource: Comic book A Story that needs an end

The fearful of Mônica's face contrast with the smile and open arms of Zélio and with the intimidating - aggressive smile of the ghost drug dealer. The kid's pink world is tarnished by the drugs and this must end.

\subsection{The family facing the drugs}

The prologue of the comic book shows a dialogue between Zélio's parents when they miss some value objects at home, such as, camera, watch and jewelry. Zélio observes them, in the sequence, leaves home in a hurry. At this moment the story teller states that the character could be someone quiet, calm and playful but he is not (p.3).

In the following strip, during the character and the drug dealer meeting, the boy talks about the difficulty, in getting money for the drugs once his parents were missing what he had hidden sold. Besides the drug dealer, taken from his human features, is represented with an aim of strengthening and inputting negative scary qualifications to the character, forwarding us to the classic bogeyman of the kids stories is used a devoted tactic of grooming Zélio by the drug dealer (picture 2) while convicing him to offer drugs to his friends as a means of increasing sales and make it cheaper those to be used by the character himself. Concerning the diversity practice use, the idea of the strip strengths an urban legend on the ways the drugs are spread among the kids and youngers in our society, increasing myths and prejudgment in the social relationship (HART, 2014) than explaining the real means of dissemination of the use of drugs among youngers and kids.

\section{Picture 2 - Grooming of the kid by the drug dealer}
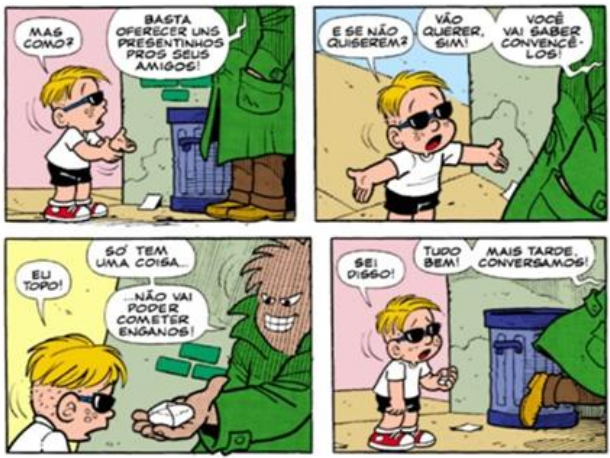

Resource: Comics a Story that needs and

Concatenated in a gradual sequence that equals use to trouble use and addiction - another common resource among the educational prohibitive material - it strengthens a more alarming function than a preventing one keeping invisible real forms of propagation of the use among kids and youngers. 
Besides, it makes a mistake by enunciating the user of the illicit psychoactive substances as invariably addict. While making reference to illicit drugs using behaviouring data out of the context - in the case of aggressiveness and lack of concentration - with no connections with life context (family, school, social) and with the specify of each substance, it contradicts what shows picture 4 and perpetuates an unreal concepts about the effect of the drugs.

The relation between the user of marijuana, as it is the case of the character Zélio, with aggressiveness it is of a historiography interested in condemning social groups, as the black ones, from a time in which science used atavistic biologists principles to justify prejudgment, segregation and extermining (SILVA, 2015), and it doesn't keep a relation with the real effects of the substance (ACSELRAD, 2015), the ways kids and youngers have to access drugs are many. Many times, those are part of the family dynamics, neighborhood, and group of friends of those, it is a mistake that the kids and youngers are groomed for the use of drugs by unknown ones or inescrupulous friends, bidding the idea of entering the "world of drugs" that exist aside from the world where we live. Sharing specitic codes and values is part of the accepting-belonging-excluding practice of any social group.

We observe that parents do not talk about behavior changes of their kids in their routine and habits, (changes on feeding, sleeping, friendship), not even the black glasses used by him seems to call attention of parents. Only when they get to know that he is making use of drugs the mother makes connections with the son's behavior (picture 3).

\section{Picture 3 - Recognising changes in behavior}

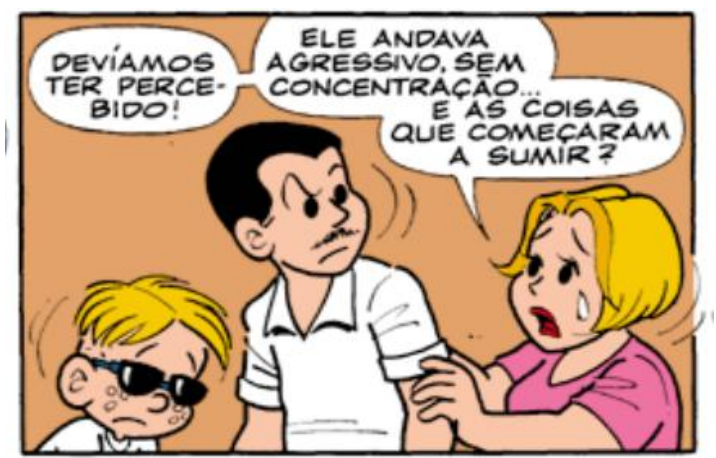

Resource: Comics a Story that needs and

For all matter, this point reinforces the individual guilty for the consumption of drugs, even by kids or youngers, so that family, society, state can be free from suchresponsibity mainly at the last word given by the user. However, in education, especially for youngers, on the other hand such freedom can not be applied once these youngers are depedent of an adult orientation and deliberation thus they need to be protected and cared by adults.

Such guardianship is progressively dismissed as that the autonomy to take decisions grow which is built through the educational process and must come from the reflection capacity acquired from a set of data and knowledge furnished in order to give support to choices made. Those who let themselves be managed thoughtlessly by established costumes do not express liberty and can't be blamed of any legal statute.

Those are basic prerogatives so that education works as a changing social process. This means recognize that education implies a kind of insubornation to social agreed injunctions and other opinion even if we point out some choices more beneficial and assertive than others. It lies on this principle the guarantee to individual liberty so expensive to liberal democracies.

\section{Picture 4 - Character smoking marijuana}
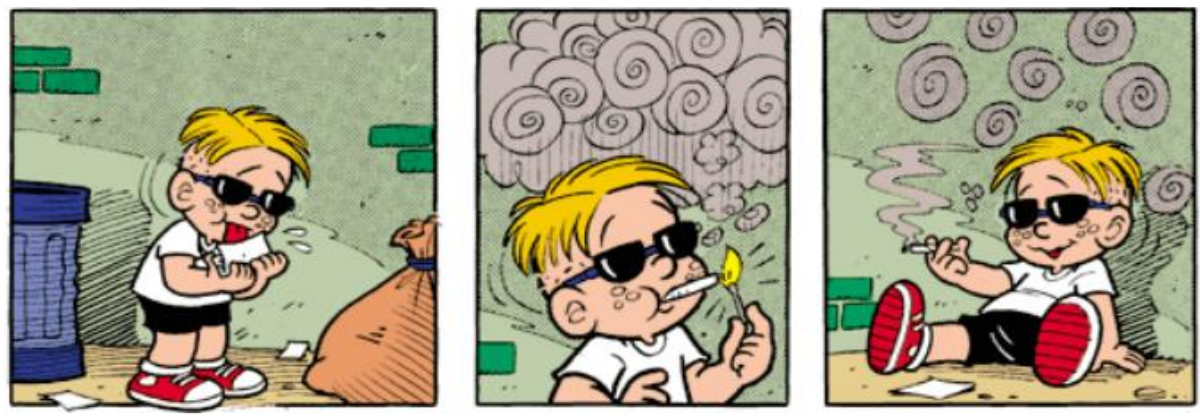

Resource: Comics a Story that needs and 
The sequence is also less common in reality than the tests intends to show (picture 4), once the group use overcomes the individual among youngers. It is in a group that the choices and reasons for the use of psychoactive substances are defined (going out with the group to - or after drinking, smoking etc; look for adventure and pleasure), the learning acquisition about drugs is shared (its effects, risks to health and body) and identity of the psychoactive substance is forged in its political-ideological dimension (get a meaning and a sense the act of using drugs) does not consider the gregarious aspects of the drugs and the individual responsibility implying in inpulting individual penalties too. The solitary use of drugs is more common among those who have defined a life style in which psychoactive substances are part of this world not be common to kids at "Turma da Mônica" age.

The dehumanization of the drugdealer's appearance is intentional, in a caricature manner, being similar to villains and witches of infant dangers of the drugs, it also helps to cultivate and consolidate the acception of tougher treatment by the law and the police for users and drug dealers. This is a domestication element that naturalizes violence and reinforces the absence of empathy in relation to the destiny of the drug dealer and makes it indifferent if it will be death or prison, if there will be bad treatment or torture (picture 5). Anyway, this concept of deserving reinforce the individual guilty. In the headings of picture 5, we observe and alternation of the verbs need and deserve, the first brings the defense idea necessity, care and as the second the idea of it deserves it, it is subjected to his right, and this justice.

\section{Picture 5 - Drug dealer and user treatment}

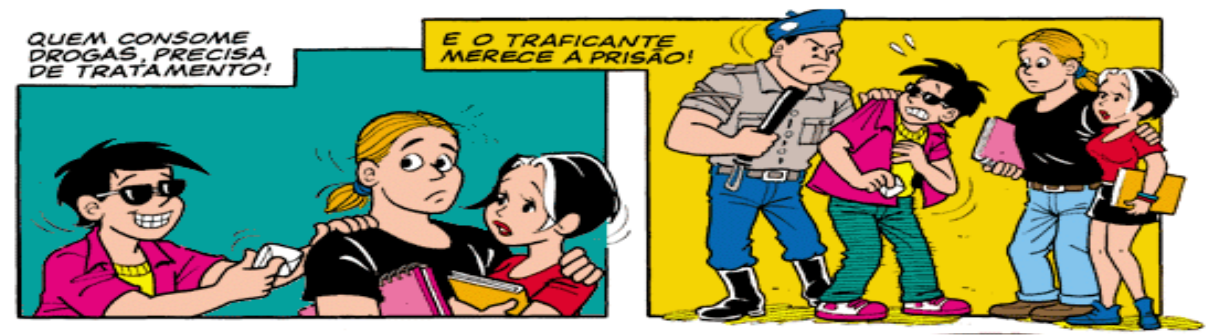

Resource: Comics a Story that needs an end.

Still analyzing the naturalization form that the text may suggest, we will point out another character, Zé Luiz, a younger a little older, a friend and protector of the kids. He appears at the story at the moment Zélio offers drugs to Mônica and group. Alert and taking care of the group, he rebukes the boy (Picture 6), inform the adults Zélio's situation (Picture 7) and makes sure that the "Turma da Mônica" is not more annoyed by the boy. For this, he certifies that the young user is taken to treatment independently of his wish (picture 8). Through the aggressive, punishing-repressive attitude of the police, Zé Luiz is the personification of the war against drugs and policing of the user. In the comics, these functions behavior bring a kind of naturalization of the use of force and violence used with the boy. Thus underlies the idea of necessity, from one side, justifying the closed wrist, the screaming and the physical force (Picture 6).

Picture 6- Reprimand the user
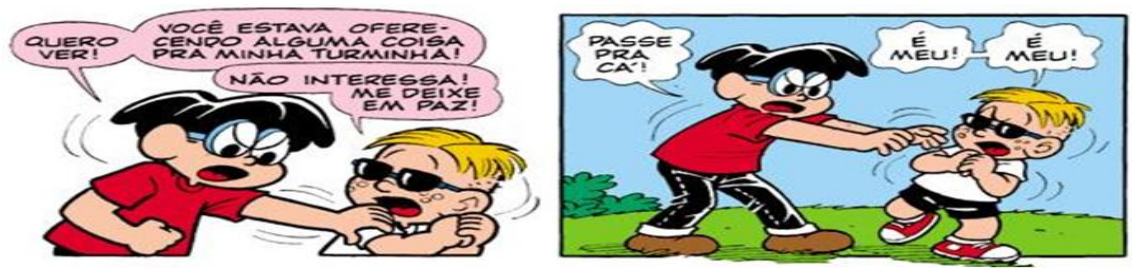

Resource: Comics a Story that needs an end.

Picture 7- The character Zé Luiz takes the subject to the teacher
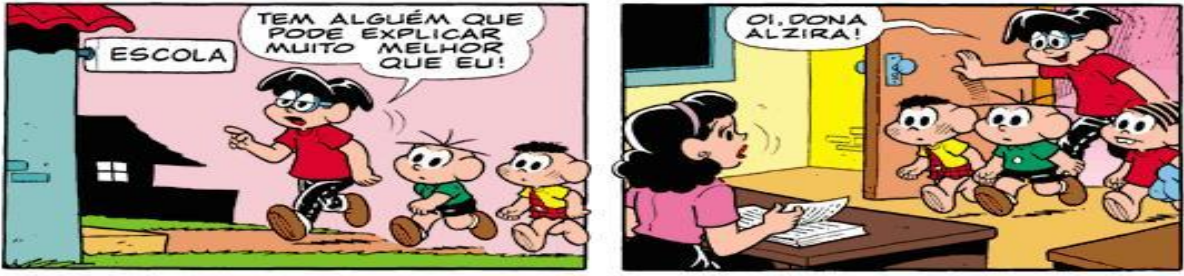

Resource: Comics a Story that needs an end. 


\section{Picture 8 - Teacher and the information on drugs}
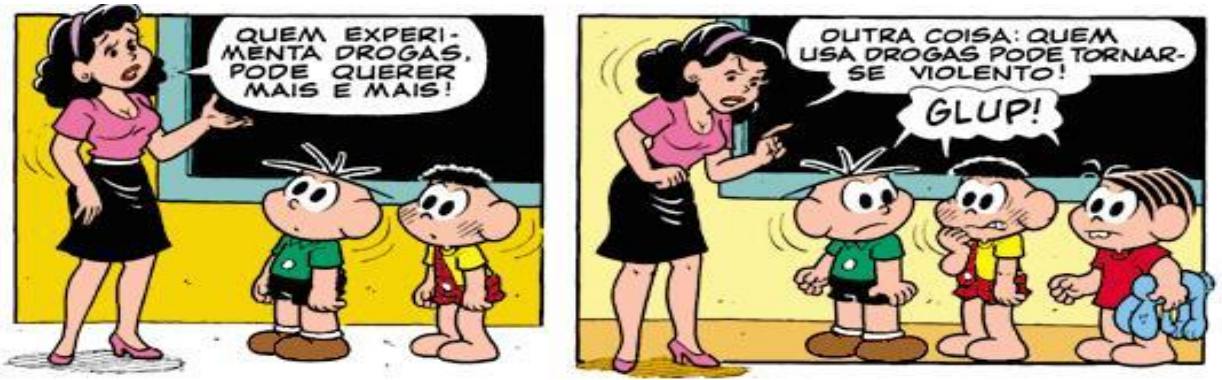

Resource: Comics a Story that needs an end.

Picture 9 - Drugs effects

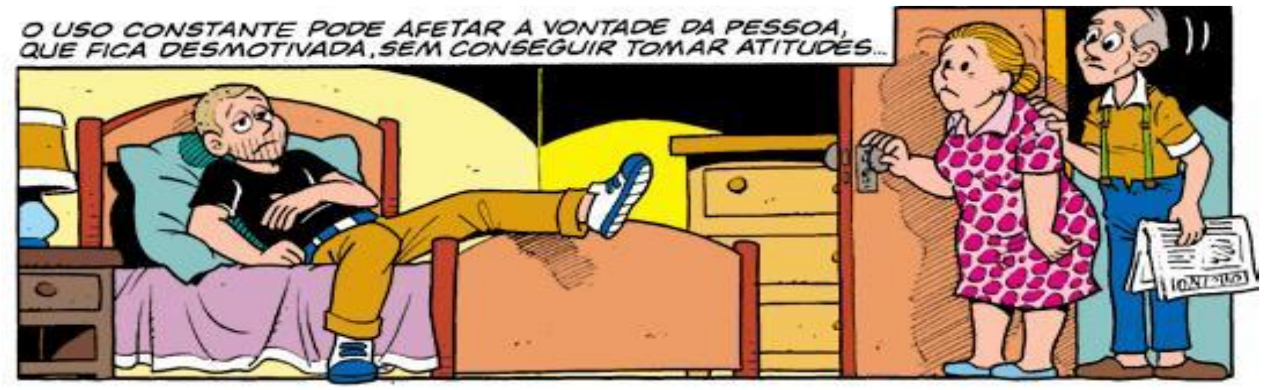

Resource: Comics a Story that needs an end.

Zé Luiz embodies the new government citizens and the decree nr. 9761, in relation to the present National Drugs Policy that, defines who is responsible for decreasing the demand and offer of drugs, in its chapter on the National Drugs Policy it states that:

3.14 Educate, inform, prepare and form people in all social segments to efficient and resulting actions in reducing the offer and demand, based on scientific knowledge and experiences well developed adequate to the national reality, supporting and fomenting services and institutions, public or private, acting in the field of continuous-capaciting education related to the undue use of drugs and tabacco addiction and its derivates, of alcohol and other drugs. (BRASIL, 2019).

Contrary to any pedagogy that praises for a progressive construction of autonomy of the kids, the "Turminha da Mônica" has little importance throughout the story, once it is shown as a core threatened and protected by the youngers and adults, the actuation in the story of the protection instances, such as the school and the family, necessary and oportuns, does not give the chance for a reflection and learning moment in the story meaningful one on drugs. Following the orientation in the NCP, Maurício de Sousa and his team emphasize the role of the school and teachers in dealing with questions related to drugs (Picture 7).

The hornbook states at the speech point three aspects about the teacher's attitude to be mentioned:

\subsection{1 - The teacher must share knowledge about drugs with students.}

Through the speeches however, the knowledge shared by the teacher contradicts what the speeches affirmed previously, as it can be noticed when it is compared picture 8 with 4 and 9.

\subsection{2 - The teacher must inform the family.}

She needs to establish a care net and assistance (picture 10). One the other hand, the initial speech of the teacher in picture 11 is not in accordance with NCP: "To Zélio there is only one way out, quit the drugs". Even through this heading production condition in the plot, links it inevitably to the kid in question, it is important to mention that this is not pointed out in the NCP, only attention and care to those who make undue and problematic use of psychoactive substances. In this case, the private becomes passable of generalization. 


\section{Picture 9 - Drugs effects}

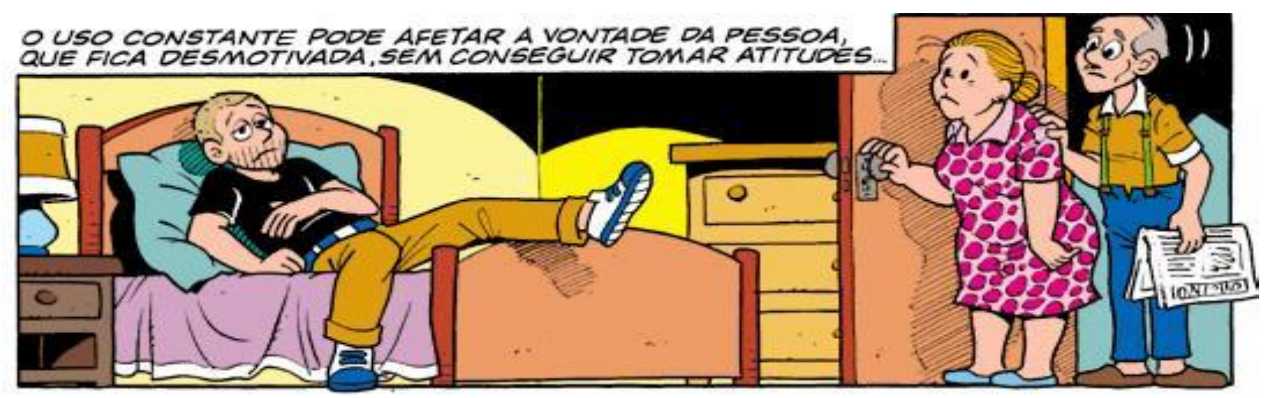

Resource: Comics a Story that needs an end.

Picture 10 - Teachers and the alternatives to solving the question

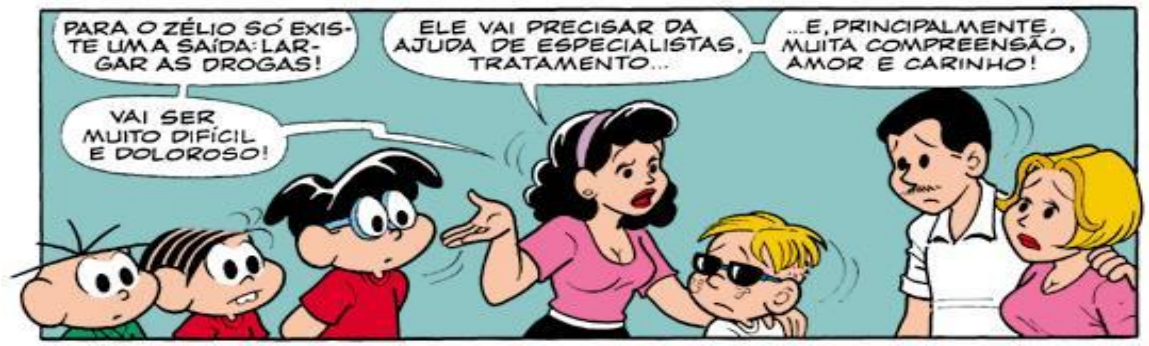

Resource: Comics a Story that needs an end.

It is thus registered that the heading "quirt the drugs" makes it uptodate a political-ideological axiom of the war to drugs, no matter what, the abistinance, showing a remaing important approach on the prohibition in the deep of a story that intended to show, in 2002 the new educacional proposal for drugs, oriented to abstinence the NCP concerning the promotion of debates about the theme at the school area as the protagonism of the teacher in dealing with the questions relate to the topic. Updating the question, the heading reverberates a recent created national policy for drugs, in which exterminating them was back to surface with all force.

\subsection{3 - The teachers fit teachings of appreciation of life.}

The class receives attentively all the information shared by the teacher as the experiences faced thought the plot, speechless or without any intervention or manifestation cover passively the story. The only exception occurs whenMônica's character hit the drug dealer followed by the teacher and with her consent. Which is already adhered to what she has seen during the plot (Picture 12).

The subreptic involuntary hospitalization of the boy Zélio is present at picture 13, introduced by the speech, "times after time..." and completed by Cascão's character talk: "Long time!", making it clear the removal of the character for undetermined time. Zé Luiz character talk installs a changing idea and provokes the reader to observe a Zélio, smiling, friendly and not wearing black glasses.

\section{Picture 11 - Teacher and appreciation of health and life}
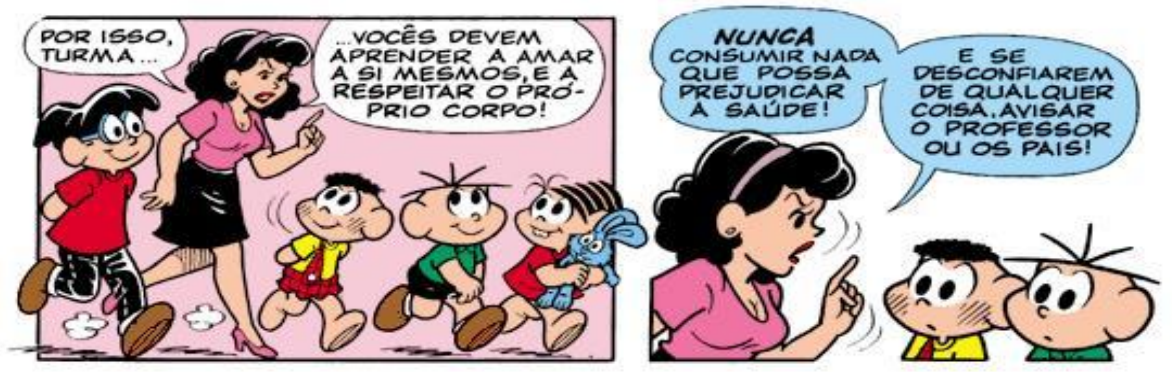

Resource: Comics a Story that needs an end. 
Picture 12 - Monica assaults the drug dealer

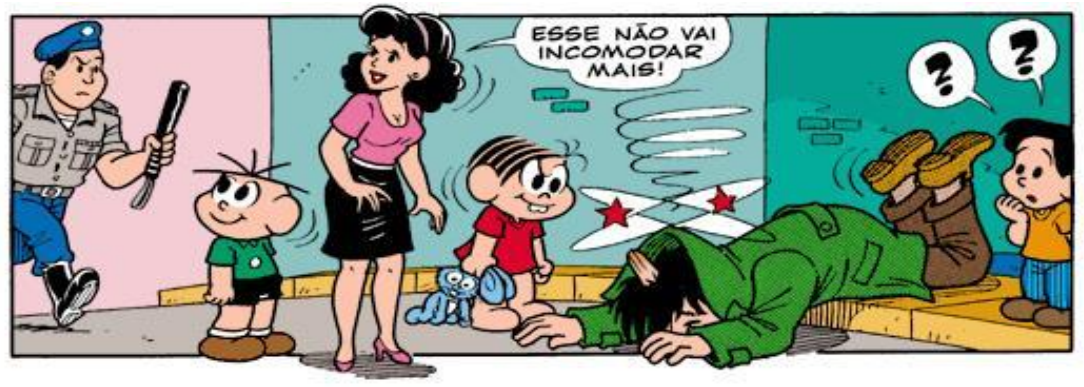

Resource: Comics a Story that needs an end.

Picture 13 - After hospitalization

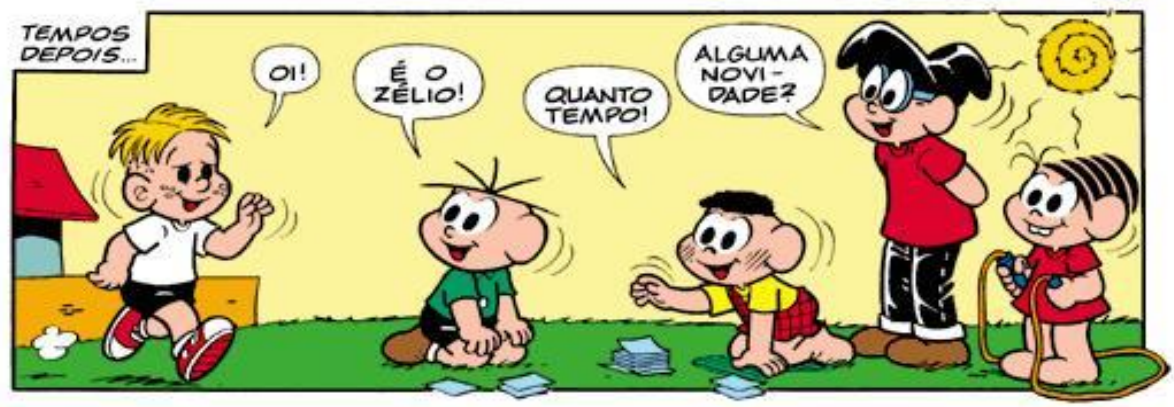

Resource: Comics a Story that needs an end.

\section{4 - Final Comments}

At the time of the release of the comic book, in 2002, it was important to promote the defense of debates on drugs at schools as to give protagonism to teachers once there was a new legislations to be adapted by education professionals. However, we have seen through the plot the defense of principles which were not befitting to such law, evidencing the ambiguity of the text and the difficulties in promoting concept advance and a sliding of the sense of the theme. For not criminalizing the debate at school and reaffirming the protagonism of the teachers, there has been advances; considering all forms of of use as addiction, use the force, indicate unitary solution for the abstinence, these still remain. By reafirmg a minimum curriculum for the drugs ${ }^{4}$, here expressed by the description of the effects of the drugs in the body and the damage and risks of the use to health (SILVA, 2019), these still are remaining. There are more remaining's and ruptures than advances, the comic book was well received by Brazilian schools and it remains like that for years.

Oppositions present at the plot, such as "Turma da Mônica" behavior and Zélio's conduct update throughout the plot the polarization expressed at the comic book cover. In the plot we meet an active Zélio, who takes decisions even being morally condemned ones (he steals, buys and uses drugs, sells things, fights, complains). This shows an autonomous kid initiative one who does what is of his interests. As it is a negative autonomy once it is related to drugs and drug dealers, it is easy to place it into the rebellion and insubordination that must be canceled. The "Turma da Mônica" behaves, on the other hand, in a passive way in several senses; to Zélio's harassment, Zé Luiz' s intervention, the situation faced by the friend, the orientation and teachings of the teachers. The only exception occurs when the drug dealer is hit by Mônica. taking into account the devoted character's mood, the action may suggest a way out to solve the problems.

\footnotetext{
${ }^{4}$ The author calls the irreducible minimum curriculum the set of consolidated knowledge in the field of drug education, anchored in health promotion. This curriculum comprises the following points: 1 - The classification of drugs, exclusively considering medical conventions and without taking into account what daily practices of use may provide as an additional element and instability to these classification criteria; 2 - Its effects on the organism, always listed in the key of dependence and suffering; 3 - The damages and / or risks arising from its use, always considering the dependence as inexorable destiny. (SILVA, 2019).
} 
In the polarization between good and bad behavior, and the good and the bad, which make Zélio's autonomy, curiosity, the exercise of his wishes, while, the "Turma da Mônica", on the other hand, is a viewer of situations, accumulating pure and innocent information anti the threats to which respond with fear and surprise until the moment Mônica acts and her iniciative is praised by those who were present. The rupture of the passivity discharged to Mônica's aggressiveness, justified by the treatment deserves the drug dealer, makes the "Turminha" develop sense defense: the defenselessness become the vigilant one.

Those who launched the fake news, making the comic book as a representative of the new government, lean on the updates of the headings inside which go into the direction of the new national policy for drugs. However, they do not take into account the impossibility of delimiting sense assimilation prescriptive horizons by kids, youngers and teachers as well as the pedagogic force of those.

As pointed out in the plot and reforced by literature, school and family gain visibility when it concerns the use of substances by kids and teens. The context of the formal teaching thus, is a potential environment for investment in terms of promoting health. For this reason, resources as the comic books may be potential material to dialogue with kids and estimulate their participative and critical sense. The opening for debates at school may let be reported the previous knowledge of these students, building dialogue trustful, remeaning, learning spaces to them.

\section{Bibliography:}

ACSELRAD, G. (2015). Quemtemmedo de falarsobredrogas? Saber mais para se proteger. Rio de Janeiro: FGV. BAKHTIN, Mikhail. (1986). Marxismo e Filosofia da Linguagem. São Paulo: Hucitec.

BRASIL. (1998). Ministério da Educação e do Desporto. Secretaria de Educação Fundamental. Parâmetroscurriculares nacionaisterceiro e quarto ciclos do ensino fundamental:Saúde. Brasília, DF: MEC/SEF.

Lei n. 11.343, de 23 de agosto de 2006. Dispõesobre o Sistema Nacional de PolíticasPúblicassobre Drogas. [Online]Available:http://www.planalto.gov.br/ccivil_03/_ato2004-2006/2006/lei/111343.htm. (July 26, 2019).

COELHO, F. J. F. Educaçãosobre Drogas e Formação de professores: umaproposta de ensino a distânciacentradanaRedução de Danos. Tese de Doutorado. Pós-Graduaçãoem Ensino emBiociências e Saúde (PGEBS), Instituto Oswaldo Cruz, Fiocruz. 2019. 245 p. [Online]

Available:https:/www.arcafiocruz.br/bitstream/icict33230/ffrancisco_coelho_ioc_dout_2019.pdf.(July 25, 2019).

ESTADÃO.Turma da Mônicavaientrarnaluta contra as drogas.[Online] Available: https:/brasilestadao.com.br/noticias/geral,turma-da-monica-vai-entrar-na-luta-contra-as-drogas,765192.(September 08, 2014).

HART, C. (2014).Um preçomuito alto. 2014. 1. Ed. Rio de Janiro: Jorge Zahar, 2014.

REVISTA DA TURMA DA MÔNICA SOBRE DROGAS NA INFÂNCIA. Mauricao, 2011. [Online]. Available: https://mauricao.wordpress.com/. (August 08, 2018).

SARMENTO, MJ. (2002). Imaginário e culturas da infância - Project: “As Marcas do tempo: ainterculturalidadenasculturas da infância". pp.1 - 17.

SILVA, ML. (2015). Drogas: da medicina à repressãopolicial. Rio de Janeiro: OutrasLetras. . (2019). "Educaçãosobre Drogas: ensino, pesquisa e extensãonaconfluência da formação do profissional da educação". In: COELHO, FJF; TAMIASSO-MARTINHON, P; SOUSA, C. (Eds.). Educaçãoemciências, saúde e extensãouniversitária. (pp. 73-84). Curitiba: Brazil Publishing.

SOUSA, M. Turma da Mônicaem: Uma história que precisaterfim. Brasil. Secretaria Nacional Antidrogas. [Online]. Available: https://www.sbp.combr/fileadmin/user_upload/Revista_Da_Turma_Da_Monica_Sobre_Drogas.pdf. (June 11,2018).

VERGUEIRO, W; RAMOS, P. (Eds.) (2009). Quadrinhosnaeducação: da rejeição à prática. São Paulo: Contexto.

ZWETSCH, BM. (2013). Educaçãosobredrogas junto à populaçãoemsituação de rua. Graduation Work (specialization). UFRGS, Porto Alegre. Available:

https://ume.ufrgs.br/bitstream/handle/10183/78028/000898053.pdf?sequence=1\&isAllowed=y.(February 16, 2019). 